\title{
RENOVATION AND MONUMENTALITY IN SOCIAL HOUSING: ANALYSIS OF DEMOLITIONS OF TOWERS AND SLABS FROM THE CASE STUDY OF THE LYON URBAN AREA IN FRANCE
}

\author{
Laëtitia Mongeard (D) - Vincent Veschambre \\ UMR 5600 Environnement Ville Société \\ 18 rue Chevreul, 69007 Lyon: France \\ e-mails: laetitia.mongeard@ens-lyon.fr • vincent.veschambre@mairie-villeurbanne.fr
}

\begin{abstract}
Large buildings (towers, large slabs, etc.) dating from 1965 to 1974 are one of the five main targets of the Agence Nationale de la Rénovation Urbaine (French National Agency for Urban Renewal), which has used demolition as a privileged tool of intervention in large social housing complexes (grands ensembles) and degraded condominiums since the early 2000s. Using a corpus of grands ensembles in the urban area of Lyon of interest to the national programme of urban renewal, we sought to verify the intentions displayed at the national level; this urban area has indeed been at the forefront of concerns regarding 'city policy' since the early 1980s and can be considered emblematic of national policies in this area. We simultaneously examined the methods used to demolish these towers and bars, from explosive demolition to mechanical means. Given their monumentality, these buildings are most restrictive at the technical level, and the means by which the demolition occurs are viewed with the greatest attention, as decision-makers are most vigilant regarding their effects on the inhabitants and on public opinion. The demolition of these high-rise buildings can be analysed in light of technical and normative evolutions (security, recycling) as well as their political and ideological meanings.
\end{abstract}

\section{Key words}

urban renewal - social housing - Lyon $\cdot$ monumentality $\bullet$ demolition - towers and slabs

\section{Introduction}

Initiated in the United States (HUD 1996; Cuomo 1999), the renewal of social housing districts is currently underway in much of Europe (Dekker \& Van Kempen 2004; Droste et al. 2008) and involves a deep urban and social transformation (Deboulet \& Lelévrier 2014).

In this paper, we examine this process in the context of France, the Western country with the greatest concentration of housing estates (Dufaux \& Fourcaut 2004). Tower blocks, which have been present in the 
suburbs of Paris and Lyon since the 1930s prototypes, were partly inspired by the American 'skyscraper' (Vieillard-Baron 2004). In France, residential towers have been historically associated with social housing; two innovations were the entrance towers of the Quartier des Gratte-Ciel ('Skyscraper District') in Villeurbanne (19 floors, 60 metres ${ }^{1}$ ) (Clémençon et al. 2004) and the five 15-storey towers of the housing estate of La Muette in the Paris suburb of Drancy - two sets of buildings created for social housing in the 1930s.

Of all the buildings constructed using state support during the period of housing estate development (1953-1973), ${ }^{2}$ tower blocks and slab blocks are undeniably part of the novel landscaping created at the outskirts of cities. As summarised by the architect Jean-Patrick Fortin, "Even an untrained eye can perceive, standing out from the existing urban structure and without any organic relation to it, an autonomous scattering of horizontal buildings - slabs - rooted in the landscape by three or four towers" (Fortin 2005: 117). Fortin adds that "it is easy to understand why the word 'tower', which recalls the imagery of belfries and steeples, is used for 14-storey buildings with 6 to 8 dwellings per floor" (ibid:: 117). The diffusion of this architectural form, minimally defined (in French) as a "construction whose height far exceeds its width", 3 is linked to what has been described as the verticalisation (Frey 2011) or monumentalisation of social housing during those years (Veschambre 2011). This monumentalisation is all the more spectacular because it is often expressed on plateaux overlooking already urbanised valley bottoms. According to the architect Christian de Portzamparc, the 'monumental' refers to "an effect of presence in space, due to shapes, dimensions",

1 http://lerizeplus.villeurbanne.fr/arkotheque/ client/am_lerize/encyclopedie/fiche.php?ref=57 [15 December 2018].

2 According to Christine Mengin (1999), this corresponds to approximately 6 million housing units.

3 http://www.le-tresor-de-la-langue.fr/ [15 December 2018]. and must be distinguished from the monument "as a sign and trace of something" (De Portzamparc et al. 1999) 4 .

The tower and the slab imposed themselves as not only the preferred form among modernist architects and planners hostile to the sprawl of standardised individual housing but also the product of an economic logic favouring the industrialisation of the building sector in the context of a housing shortage; under the influence of the Athens Charter, the goal was to free up space on the ground, to seek air and light, and to rationalise the production of social housing both vertically (the crane) and horizontally (the crane track) (Vayssière 1988; Collectif5 2011).

The so-called 'Towers and Slabs' circular of 30 November $1971,{ }^{6}$ which applied to small and medium towns, dealt a first blow to these urban and architectural forms; it is said that "The character of this type of agglomeration risks being compromised by a form of construction described in ordinary language as 'towers and slabs'. These buildings are objectionable insofar as they disrupt an urban landscape that we must strive to preserve". With the circular of 21 March 1973, Olivier Guichard extended the prohibition of the use of this type of building for social housing to all French agglomerations.

The early discrediting of this architectural production was further exacerbated by the departure of the middle classes and their replacement by precarious populations from the 1970s onwards. While the desire to create a clean slate regarding the issue was first expressed in the early 1980s, it was only after twenty years of politique de la ville (urban policy) - i.e., state-driven territorial actions,

\footnotetext{
${ }^{4}$ Le 'monumental' renvoie à "un effet de présence dans l'espace, dû aux formes, aux dimensions" et doit être distingué du monument "comme signe et trace de quelque chose" (De Portzamparc 1999).

5 Agence d'urbanisme de l'aire métropolitaine lyonnaise, 2011; Atlas du logement social du Grand-Lyon, 2011.

${ }^{6}$ Circular on forms of urbanisation adapted to medium-sized towns, signed by the Minister of Equipment and Housing Albin Chalandon and Secretary of State for Housing Robert-André Vivien.
} 
including housing rehabilitation and social development in the so-called 'priority neighbourhoods' - that the taboo on demolition was finally overcome (Berland-Berthon 2009).

These high-rise buildings, which formed the structure of most large housing estates and profoundly marked urban peripheries, were indeed the first to be targeted in the early 2000s by those who promoted a new urban renewal policy.

Our aim was to return to the ways of treating towers and large slabs in urban renewal operations, given the characteristics implied by the scale of these buildings: a concentration of a large number of dwellings, a call for restrictive techniques in case of intervention on the frame, and high visibility. Thus, through a corpus of neighbourhoods of social housing in the urban area of interest of Lyon to the National Urban Renewal Program, to which we have added some peripheral examples within the Pôle Métropolitain, we sought to verify the intentions displayed at the national level; since the beginning of the 1980s, the urban area of Lyon has been at the forefront of 'city policy' concerns and can be considered as emblematic of national policies.

We formulate a hypothesis regarding a particular treatment of towers and slabs in the context of urban renewal operations because of their monumentality. Monumentality is defined as the "building a remarkable event in the ordinary landscape of an agglomeration" (Gravari-Barbas \& losa 2006). To this physical dimension, it is generally necessary to add a symbolic dimension associated with the notion of power (ibid). It must be pointed out that this monumentality of large buildings is paradoxical: it is today not associated with power and elites but with poor populations, a form of symbolic inversion took place during the latter decades. We will consider for our analysis the exceptional character of the architectural dimensions and the

${ }^{7}$ Construction d'un événement remarquable dans le paysage ordinaire d'une agglomération (GravariBarbas \& losa 2006). symbolic value of the buildings. We hypothesise that the interventions carried out in the context of urban renewal have implemented a particular treatment of monumentality. This particular treatment can be analysed by considering this building characteristic to decide whether or not to demolish it, but also, in the case of demolition, by implementing an unusual means of demolition.

\section{'Large' buildings in urban renewal programmes and discourses}

\section{The tower (and the slab): \\ A favoured target of urban renewal during the years 2000-2010}

"Ten years ago, the ANRU (National Agency for Urban Renewal) was primarily the weight of words, those of an urban planning minister, Jean-Louis Borloo, who wanted the state and its partners to invest heavily via an agency in relegated neighbourhoods, in order to give meaning to the lives of millions of residents. It was also, very quickly, the shock of images (Fig. 1), as the first towers and slabs were demolished to rebuild a livable city". ${ }^{8}$

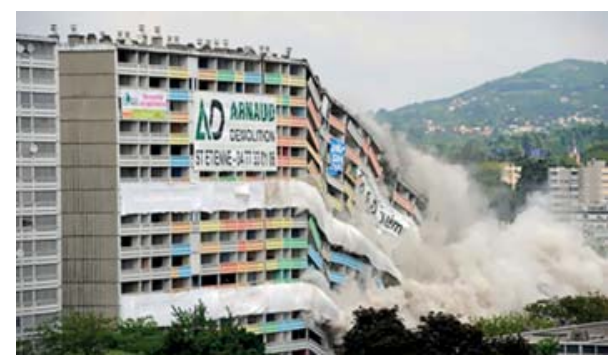

Figure 1. Explosive demolition of a slab of approximately 300 housing units

Source: Michel Djaoui, Opac du Rhône - Lyon La Duchère, 2010

The 'weight of words' was essential to instigating this large-scale policy. Established by the Borloo law of 2003, the ANRU

\footnotetext{
${ }^{8}$ Anne Peyricot, ANRU Director of Institutional Relations, "Redonner du sens à la vie de millions d'habitants," 12 March 2015, http://www.anru.fr/index. php/fre/Actualites.
} 
specifically targeted, among the buildings to be demolished as a priority, 'large' buildings dating from the 1965-1974 period in particular, tower blocks now diagnosed as being technically poorly adaptable and sociologically 'badly inhabited'.

With the recent launch of the new National Urban Renewal Programme ${ }^{9}$ (also known as PNRU2) in 2016, the time has come to assess the National Urban Renovation Programme (PNRU) instituted according to the law of 1 August 2003. Both the plans have focused mainly on social housing districts - i.e., the so-called 'priority districts' of the politique de la ville. As indicated by the choice of the term 'renovation'10 the PNRU (2003-2016) distinguished itself from the previous politique de la ville both by the massive scale of investments made (EUR 45 bn between 2003 and 2015) and the emphasis placed on demolitions aimed at significantly modifying urban and architectural forms inherited from the period of housing estate development (1955-1973). Within the framework of agreements that brought together the central state, local authorities, and social housing landlords, the ANRU wielded its influence so that each of the funded programmes would include the demolition of several housing units under agreements signed for the different social housing districts. While far more units were ultimately rehabilitated than were demolished and rebuilt, demolition on such a large scale is unprecedented. This priority can be seen in the ANRU budget structure, ${ }^{11}$ which is in charge of managing the PNRU. Indeed, the first entry in the budget concerns demolition. ${ }^{12}$

\footnotetext{
${ }^{9}$ Established by the Law on City Programming and Urban Cohesion, promulgated on 21 February 2014.

10 In 2003, the term 'urban renovation' supplanted that of 'urban renewal' in official texts.

11 This budget represents about one quarter of the PNRU overall funding.

12 136,000 demolished units, 109,000 rebuilt units, 294,000 rehabilitated units. See Mémo PNRU les chiffres 2015 - https://www.anru.fr/fre/Mediatheque/Publications/Memo-PNRU-2015-Les-chiffres [20 December 2018].
}

Under the signed agreements (approximately 400 between 2003 and 2015), the ANRU has systematically stressed its stated demolition objectives and repeatedly demanded an increase in the number of buildings to be demolished during negotiations with local actors, local authorities, and social housing landlords. Not merely any type of building was targeted by the PNRU as part of its demolition component; rather, the following four targets were defined as priorities $^{13}$ :

- "Old buildings dating from before 1948" ( $2 \%$ of the stock to be demolished);

- "Old economic programmes (emergency housing estates, Million programme, family housing (LOPOFA), social relocation programme (PSR))", corresponding to buildings that were produced at low cost and have therefore become obsolete or even antiquated (10\% of the stock to be demolished);

- "Ordinary buildings dating from the 19501970 period" (10 to $30 \%$ of the stock to be demolished);

- "Large buildings (tower blocks, large slab blocks, etc.) dating from the 19651974 period" (40 to $50 \%$ of the stock to be demolished).

While this last category of buildings (slab and tower blocks) is the most important quantitatively, it is also central to the arguments developed around the PNRU. At the office of a social housing landlord in Angevin, an urban renewal officer who had followed the agreement negotiations reported that an ANRU manager had stated, "We don't rehabilitate towers". ${ }^{14}$

\section{Tower blocks and large slab blocks in urban renewal discourse}

Towers and the largest slab blocks are therefore among the priority targets of urban

\footnotetext{
13 See the 2003 finance bill: https://www.senat. fr/rap/a02-070-23/a02-070-2314.html [15 December 2018].

14 Interview with an urban renewal officer, Angers Habitat, June 2005.
} 
renewal, as has been clearly stated by the ANRU. The representations that underlie such prioritisation seem very deeply rooted and are expressed in discourse (Genestier \& Veschambre 2017) that presents the social housing tower as the emblem of a decried urban form, namely, the large housing estate of the 1960s. The monumentality produced during that period was gradually associated, in the 1970s, with the social profile of impoverished populations, who often came from a postcolonial background and were unable to leave social housing initially construed as a transitory step in a residential trajectory. The deterioration of social housing due to poor maintenance by landlords and the first urban riots led to the implementation of urban policies in the early 1980s. The values traditionally associated with monumentality and verticality were thus reversed in the context of the social and material evolution of large-scale social housing estates.

Textual analysis conducted as part of an ANR-funded study on demolition in social housing districts ${ }^{15}$ allowed me to specify the location and image of the tower in the discourse on urban renewal. The corpus consists of speeches pronounced by ministers in charge of the politique de la ville (20002010), opinions issued by prefects concerning PNRU agreements (2005-2010), and articles taken from the specialist or generalist press. The daily press corpus was compiled via a keyword search (using the French equivalent of 'urban renewal', 'urban renovation', 'housing', and 'social housing') on the Factiva website. ${ }^{16}$ To browse and study this cor-

\footnotetext{
15 "Attentes et attendus en matière d'espace (AAE): la démolition dans les grands ensembles" (director P. Genestier, 2010-2013).

16 For the national newspapers, I selected Libération, Le Monde, Le Figaro, Humanité and La Croix, which cover most of the political spectrum. The daily regional press is represented by Le Progrès (Lyon region), Le Parisien and Ouest-France. Depending on availability, the corpus covers the period 1999-2010 (Le Monde, Le Figaro, Libération) or the period 2005-2010 (Le Progrès, Le Parisien, I'Humanité, Ouest-France and La Croix).
}

pus, we used Lexico3, a textometry software developed by University Paris 3.

First, we must emphasise the prevalence of the rhetorical formula that associates 'towers and slabs' - in the plural. ${ }^{17}$ In the speeches of ministers in charge of the politique de la ville, 'slabs' is associated with 'towers' 7 times out of 12; conversely, 'towers' is associated with 'slabs' 7 times out of 15. In the specialist press, which is presumably less likely to use stereotyped vocabulary when describing social housing districts, this rhetoric is still very present. In the corpus compiled from the journal Urbanisme, 'towers' is associated with 'slabs' 21 times out of 54 and 'slabs' with 'towers' 21 times out of 45 - that is to say, in almost half of the occurrences:

- Thus, it appears that the expressions 'towers and slabs' or 'slabs and towers' are sufficient to designate a problematic urban form: "Caucriauville is just towers and slabs!" (Jean Moulin, deputy mayor of Le Havre and president of Alcéane, the city's social housing office, Le Figaro, 1 June 2007, p. 22).

- According to some political actors, towers and slabs are not mere urban forms, but a genuine ideological expression: "At voting time, our opponents told us: 'You're caught up in the ideology of towers and slabs. What the French want is a house and garden.' (...) But do we have to keep all the slabs and towers? No, really, we're not Soviets!" (Yves Dauge, Socialist Party senator, Libération, 17 December 2005).

- Thus, simply uttering that hallowed expression often enough makes demolition appear self-evident: "Nearly 1,200 social housing units were built in a hurry, in the form of slabs and 18-storey towers. Today, the urban renewal project involves the demolition of 101 housing units managed by Logirep and SEMINO (Social Housing Office)" (Le Parisien, 6 December 2007, p. 3).

\footnotetext{
17 The formula is much less common when the terms are in the singular and when a specific building is being discussed.
} 
- Or argumentation seem pointless: "Pierre Bédier, in charge of housing in Mr. Chirac's campaign team, pointed out that the President wanted to revive home ownership, promote rental investment, and accelerate the demolition of slabs and towers in working-class housing estates" (Le Monde, 8 May 2002).

- Sometimes, the nature of the problem generated by these architectural and urban forms is explained by the speed of execution, which implies bad design and poor workmanship: "We built slabs and towers in a hurry" (Le Figaro, 9 November 2005)."The slabs and towers built in a hurry during the baby boom and economic growth period constitute yet another layer, unfinished and poorly designed, which must now be cleaned up and refreshed" (A. Grumbach, Le Figaro, 29 May 2000, p. 12).

- As is often the case (Gaudin 2013), the problems regarding social housing isolation and concentration, which presuppose segregation, are also associated with these architectural forms and are highlighted to justify urban renewal: "This set of towers and slabs isolated in the middle of residential areas, at the far end of Avenue Emile Dambel, will undergo a profound change in the coming years" (Le Parisien, 15 March 2007).

- "And the destruction of towers and slabs is expected to ease the situation in districts with a high concentration of social housing" (Libération, 27 May 2000).

Several commentators speak in terms of representations. While specifying that the image of towers and slabs is highly negative, they also recall that it is constructed:

- "These tower and slab districts are now the urban archetypes of exclusion. But this was not always the case" (Libération, 12 January 1999).

Conversely, it can then be deconstructed:

- "The social housing building will be transformed in the coming months. By the same token, it will be shown to be worth more than the sad reputation that often plagues 1960s slab-and-tower architecture" (Le Figaro, 15 April 2006, p. 30).

As the authors of the articles sometimes explain, this is indeed a discursive matter:

- "Slabs and towers are declared to be factors of desocialisation" (Le Parisien, 6 September 2006).

These first explorations of the discourses accompanying urban renewal illustrate the general tone; arguments in favour of demolition are not very developed because the mere mention of an urban and architectural form via the stereotype of 'towers and slabs'- suffices to condemn it. While the two terms 'towers' and 'slabs' are commonly associated, the term 'towers' is more frequently used alone; we must now specify the word's associations in the discourse on urban renewal.

From the discourse relating to towers and slabs, we would now like to consider the treatment that has been reserved for towers and slabs during the urban renewal programme in the Lyon metropolis.

\section{Magnitude and issues of the demolitions of monumental buildings: The example of the Lyon agglomeration}

To verify the actual nature of the objectives displayed in the context of the PNRU, we have taken the example of the agglomeration of Lyon $^{18}$, within the Rhône-Alpes region, the second largest French region (after Paris) in terms of the number of districts concerned with urban renewal. With an industrial tradition and today economically diversified, the metropolis of Lyon was an experimental region for the construction of large buildings of social housing ('grands ensembles'); within the framework of the Courant Plan (1953$1955)^{19}$, two of the first six large buildings,

18 Since 2016, the region like most other French regions has changed its scope to include the former $\mathrm{Au}$ vergne region. We remain on the scope prior to 2016 under which the PNRU started.

19 Initiated by the Minister of reconstruction Eugène Claudius-Petit, this plan aimed to accelerate the industrialization of the building sector through the 
and particularly, the largest number of them, Bron-Parilly, were built there. This agglomeration was also the first to be affected by the social movements of the early 1980s, which led to the adoption of a so-called 'city policy' targeting social housing neighbourhoods. The Minguettes district in Vénissieux, in eastern Lyon, was the scene of clashes between young people and police officers in the summer of 1981 and then riots in March 1983 following police violence; these events prompted the President of the Republic to visit and induce the launch of the 'city policy'.

We built a corpus (cf. Tab. 1) using all the neighbourhoods contracted with the National Agency for Urban Renewal since 2003. In this context, we were interested in the presence of monumental towers and slabs, while considering the very general definition (exceptional dimensions, potential symbolic value) and what the actors of this policy themselves designate as monumental. We also referred to thresholds, when we had access to the quantitative data.

To realise this inventory and specify the nature and extent of demolitions in the ANRU neighbourhoods of the Lyon area, we used the website of the ARRA (Regional Association of low-income housing in Rhone-Alpes), which collects information produced by social landlords. In the Greater Lyon area, where many of the districts concerned are concentrated, we were able to supplement this information with the help of the Atlas du logement locatif et social du Grand-Lyon (Atlas of Rental and Social Housing of Grand-Lyon) (2011). The

Table 1. Inventory of the demolitions in neighbourhoods in agreement with ANRU according to building type

\begin{tabular}{|c|c|c|c|c|}
\hline District & $\begin{array}{l}\text { Number of towers } \\
\text { to be demolished }\end{array}$ & $\begin{array}{l}\text { Number of monu- } \\
\text { mental towers to be } \\
\text { demolished }\end{array}$ & $\begin{array}{l}\text { Number of slabs } \\
\text { to be demolished }\end{array}$ & $\begin{array}{l}\text { Number of monu- } \\
\text { mental bars to be } \\
\text { demolished }\end{array}$ \\
\hline $\begin{array}{l}\text { Bourgoin - Jallieu - Champ } \\
\text { Fleuri }\end{array}$ & 5 & 1 & 0 & 0 \\
\hline Bron-Terraillon & 1 & 1 & 2 & 0 \\
\hline Bron-Parilly & 0 & 0 & 1 & 1 \\
\hline Lyon-La Duchère & 0 & 0 & 8 & 8 \\
\hline Lyon-Mermoz & 0 & 0 & 6 & 2 \\
\hline $\begin{array}{l}\text { Rillieux-la-Pape } \\
\text { Ville nouvelle }\end{array}$ & 4 & 4 & 1 (partial) & 1 \\
\hline $\begin{array}{l}\text { Saint Etienne } \\
\text { Montreynaud }\end{array}$ & 2 & 1 & 4 & 0 \\
\hline Saint-Fons Arsenal & 1 & 1 & 0 & 0 \\
\hline Vénissieux Minguettes & 8 & 8 & 0 & 0 \\
\hline $\begin{array}{l}\text { Fontaine sur Saône } \\
\text { La Norenchal }\end{array}$ & 0 & 0 & 3 & 2 \\
\hline Vaulx en Velin & 1 & 1 & 4 & 1 \\
\hline $\begin{array}{l}\text { St Priest } \\
\text { Centre-ville }\end{array}$ & 0 & 0 & 4 & 1 \\
\hline Villeurbanne (Les Brosses) & 0 & 0 & 2 & 0 \\
\hline Total & 22 & 17 & 35 & 16 \\
\hline
\end{tabular}

Sources: ARRA, ANRU, Atlas of Social Housing

support of some pilot operations. 
local press (Le Progrès) and the Moniteur ${ }^{20}$ at the national level have allowed me to update the information available in these reference documents.

Definition of 'monumental towers': towers of more than 50 meters, more than 10 storeys or 100 dwellings.

Definition of 'monumental bars': slabs of more than 150 dwellings.

Thus this overview will verify and evaluate the scale of large building demolitions within the framework of the ANRU. How did the national directives translate into these areas of the Lyon region?

\section{The monumental: A target actually privileged}

Monumentality was primarily targeted by demolitions in half of the neighbourhoods studied (7 out of 13 ). The evocation of the different cases of demolition of the agglomeration that follows highlights a typology of buildings taken into account: sometimes essentially the towers, sometimes essentially the slabs, sometimes the two forms indefinitely.

In Rillieux-la-Pape, Vénissieux, and SaintFons, towers were the target of almost all the demolitions. The case of Vénissieux is specific in the sense that towers predominate there; this was not the case in Rillieux and SaintFons, which were chosen specifically.

In Saint-Fons (district of Arsenal), the only building to be demolished was a 10-storey tower that housed 'The Rose Garden' managed by ADOMA, formerly SONACOTRA. Since the 1960s, this home has welcomed foreign workers, especially Maghrebians. This demolition, accompanied by a work of memo$r y$, did not give rise to visible reactions ${ }^{21}$.

In Rillieux-la-Pape, in the 'grand ensemble' known as the 'New Town', the eastern part has not had towers since February 2017 and the blasting of Lyautey 1 and 2, two towers

\footnotetext{
20 Through a press review on the years 2014 and 2015.

21 Cf. https://www.annydulac.fr/ateliers-photographiques/travail-de-m\%C3\%A9moire-autour-d-uned\%C3\%A9molition/ Consulted on 10 September 2015.
}

of 16 floors (or 54 metres). Exactly 9 years earlier, the first two towers were destroyed, marking the launch of the 'new neighbourhood of Velette-Balcons de Sermenaz' project, which will be characterised by the extension of green spaces and afforestation. Concomitant with these two demolitions, artistic devices were put in place ${ }^{22}$ to prepare the populace for demolition and to leave traces. In 2015-2016, artists' studios ('around the towers') were installed 'on the fourth floor of the Lyautey tower, a symbol of a city that is transforming itself'23. Of the 7 towers present before 2007 in the New Town, only 3 remain.

At La Duchère, in Bron-Parilly, Fontainesur-Saone and Vaulx-en-Velin in part, monumental slabs were first demolished. We can speak of structural effects in Bron-Parilly, one of the first 'grands ensembles' built in France, with the asserted choice of monumentality. This is not the case for the other three districts, within which the monumental slabs have been the subject of special treatment.

In Mermoz, district of Lyon, the demolitions focused on slabs (Fig. 2). The contrast between the two forms is particularly marked; the largest slab, which was monumental and was located at the entrance of the district and of the city upon arriving from the east, was demolished in addition to other slabs. The towers and other slabs have been rehabilitated, renamed, and have been the subject of social support for inhabitants. In this neighbourhood, demolitions of buildings were not communicated to the populace, even that of the largest slab, which was gradually demolished. Only the demolition of the overpass of the district was highly publicised.

At La Duchère, district of Lyon, the situation is particularly clear; the large slabs, which are very visible from a distance on the plateau overlooking the Saône, have been gradually erased from the landscape.

\footnotetext{
22 In 2008, the association Microphone has produced a DVD composed of words of inhabitants entitled "I had the dream view".

23 Press kit: presentation of urban projects and the Horizons Croisés program, GPV Rillieux-la-Pape, 2016.
} 


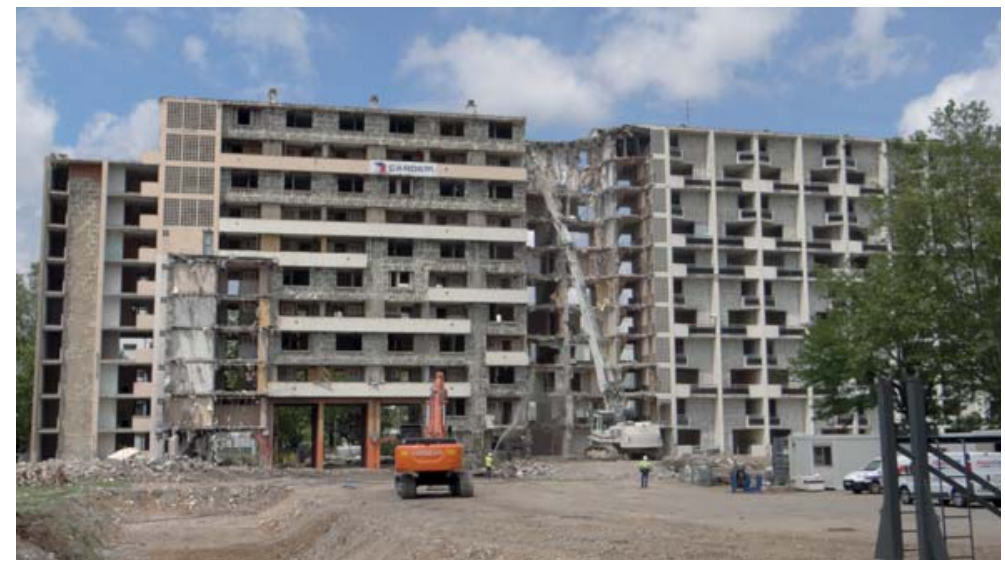

Figure 2. Demolition by nibbling of a slab in Mermoz, Lyon (2013)

The most emblematic was the 'slab of 1000', which was actually the alignment of three bars comprising nearly 1000 homes. The slabs were successively demolished in 2005, 2010, and 2015 during high-profile demolition operations. The only tower in the neighbourhood has been the subject of heritage recognition. Signed by the designer of the La Duchère district, François-Régis Cottin, the 'panoramic tower' remains the district's main landmark.

In five other neighbourhoods in the region, demolitions affected both large and small buildings. However, in all cases, it is the demolitions of towers and large slabs that have been focused on, with the publication of press articles and videos available on the Internet.

The demolition that invoked the most emotion was undoubtedly that in Saint-Etienne of the tower Plein Ciel ('full sky') of the district of Montreynaud. Built in 1972, this 18-storey tower, 64 metres high, marked the northern bypass of Saint-Etienne, with a characteristic silhouette due to its rooftop water tower. Many voices were heard, particularly in the cultural field, in favour of another outcome (Kaddour 2015). A petition was circulated noting the social nature of the diagnosis involved; inhabited by wealthy social classes, this tower could have become one of the architectural emblems of Saint-Etienne, a UNESCO city of design ${ }^{24}$. A referendum was finally organised in the neighbourhood, which decided in favour of demolition and was considered preferable by local authorities considering the socially degraded situation of the building's co-ownership. On November 24, 2011, the tower's cave-in was orchestrated as a major city event

In Bourgoin-Jallieu, four small towers of the Champfleuri Group 1, or 116 dwellings, were demolished. However, it was the largest tower, the Chopin (99 dwellings), described as the emblematic building of Bourgoin ${ }^{25}$, that attracted the most attention; the lessor accompanied this demolition with a collection of memoirs ('Chopin's life book'), and the city decided to keep the Chopin toponym as the name of the street created following the demolition.

24 "This symbolic tower of a city that makes SaintEtienne, a city different from the others, must not be destroyed. To have a reflection on the urban and not piecemeal this tower of the district of Montreynaud, built in the 70s should not be destroyed and used for other purposes. This tower should have been the most posh tower in Saint-Etienne with such a beautiful panorama. Sign if you are against this destruction." http://www. forez-info.com/actualite/divers/12342-saint-etienne-latour-plein-ciel-peut-elle-disparaitre.html [20 December 2018]

25 http://www.opac38.fr/Nos-metiers/Renouvellement-Urbain/BOURGOIN-JALLIEU-Le-quartier-Champfleuri consulted on 10 September 2015. 
In downtown Saint-Priest, the demolition affected various types of buildings. Again, it was the demolition of the bar of the Alps, a degraded condominium, that caught peoples' attention.

In Bron Terraillon, a tower and several small slabs were demolished. These demolitions were relatively discrete and at the scale of the agglomeration. The strongest emotion in the neighbourhood concerned the tower demolition. The tallest and most visible building in the area affected by urban renewal, the Caravelle Tower, a degraded condominium, was demolished due to a concentration of social problems, including drug trafficking. The tower demolition caused tensions in the neighbourhood, involving the people who previously occupied the building's lobby to former occupants dissatisfied with their relocation.

In Vaulx-en-Velin, medium-sized slabs were also demolished (Fig. 3). The presence of many slabs can lead to trivialisation of their form, which then becomes what Jean-Pierre Frey calls 'ordinary monumentality' (Frey 2011). This banalisation was offset by regrouping the demolitions; thus, the three bars were demolished simultaneously, and two more will be demolished together under the NPNRU. The event mobilised only the inhabitants of the neighbourhood.
Of the 13 neighbourhoods in our corpus, only one, that of Les Brosses in Villeurbanne, was not affected by the demolition of large buildings.

This overview of urban renewal in neighbourhoods affected by the intervention of ANRU in the Lyon region confirms the displays at the national level. More than half of the demolished buildings (33 out of 57) fall under the category 'large towers and bars', and as we have just reviewed, in almost all the neighbourhoods studied, demolitions of this type of building affirm that public authorities intervene and that profound transformations are in progress.

Demolition is an excellent indicator of the depreciation of architectural and urban forms, and, by the same token, of the inhabitants associated with them. For Pinçon and Pinçon-Charlot, "The somewhat tragic fate of these social housing towers or slabs that can be seen disappearing via implosion in a cloud of dust is indicative of the asset value of this form of housing: nil" (Pinçon \& Pinçon-Charlot 2002: 323).

\section{Demolishing large structures Exacerbated technical issues}

In most cases, monumentality is taken into account in the decision to demolish or conserve

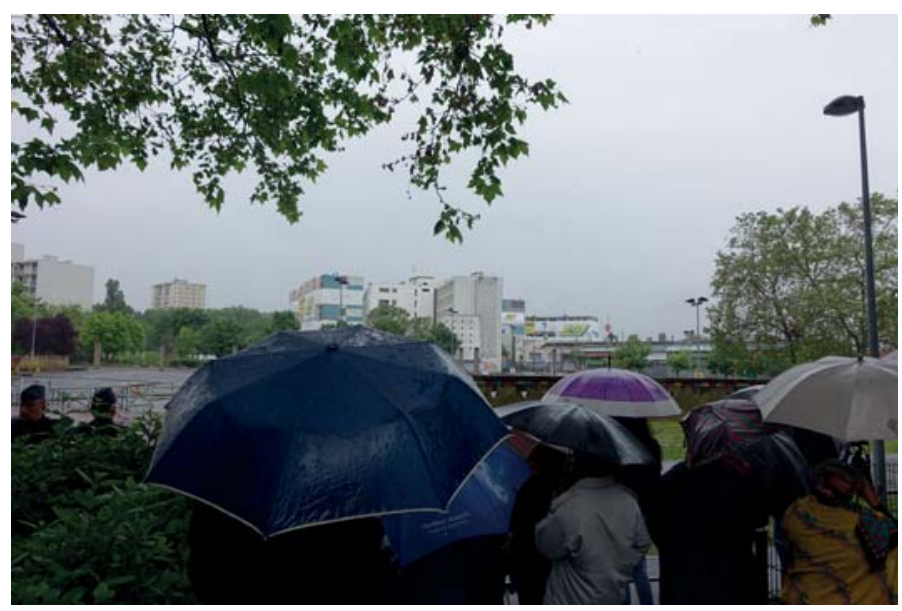

Figure 3. Waiting for the demolition with explosive of three slabs in Vaulx-en-Velin (2016) 
buildings. This frequent feature of towers and slabs also plays an important role in the method used to demolish these buildings, giving demolition a particular function. Indeed, the disappearance of towers and bars in the neighbourhoods targeted by the PNRU goes through the stage of the demolition site, whose technical aspects represent important issues that are indirectly political.

Demolition activity is now carried out in France according to two main techniques: nibbling and explosives. Nibbling - also called 'mechanical demolition'26 - involves demolishing the structure of the building using a mechanical shovel, on a relatively long arm, equipped with a head adapted to the material to be demolished (Fig. 4). In the case of concrete structures, the arm is equipped with a clip that 'bites' the building to incur a gradual fall. The explosive technique consists of piercing the walls of the building at specific points, defined by a calculation involving the building characteristics - and depositing in these holes explosive charges, which, when activated at the same time, allow the building to implode.

Of these two choices, nibbling is much more common, as only a few national companies are qualified to carry out explosive demolitions. The major reason for the infrequent use of explosive demolition is the cost of such an operation, which requires expertise and very specific materials. When interviewed, ${ }^{27}$ the manager of a demolition firm explained the scarcity of explosive demolitions by the fact that they can be used only for "important buildings, more than 200 dwellings and more than 5 floors". Hence, demolition is generally carried out by nibbling, a technique also characterised by its discretisation, moving in the direction of often-ignored operations and carried out silently upstream of development projects.

\footnotetext{
26 National Union of Demolition Contractors, www. sned.fr, consulted on 20 December 2017.

27 Interview conducted at the company's headquarters, October 15, 2014.
}

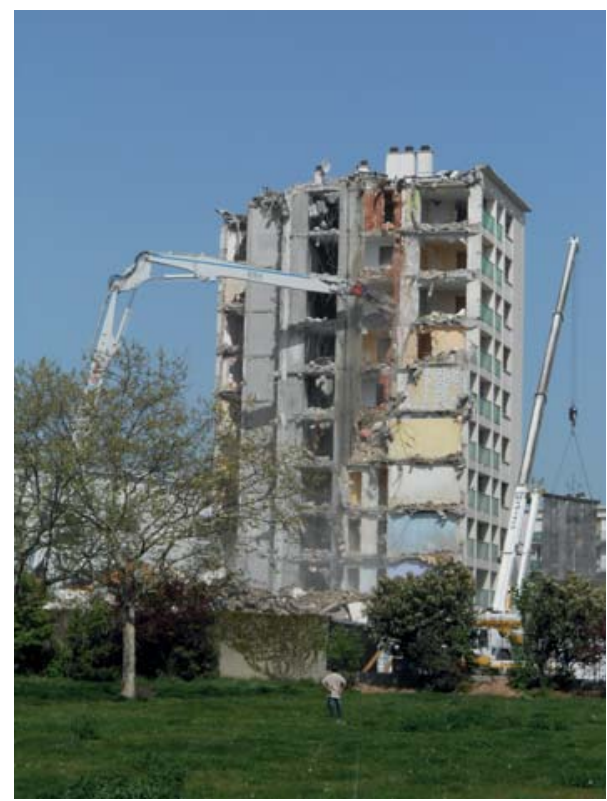

Figure 4. Demolition by nibbling of a tower in Bron-Terraillon, Bron (2013)

The demolitions carried out in the context of urban renewal are unique cases because the relatively frequent monumentality of the buildings to be demolished raises a question regarding the choice between these two techniques. In addition, nibbling becomes, for a large building, very expensive and potentially technically impossible. Indeed, the nibbling technique is subject to a technical limitation: the maximum possible building height, which depends on existing excavators owned by national or European demolition companies. This limitation echoes that in effect during the construction of these buildings: the height of the cranes. An engineer who was interviewed estimated that the maximum height for a nibbling demolition today is 50 metres, knowing that very few such high excavators exist and that moving them - from a company's headquarters with disposers - represents a considerable expense. The height limit also relates to safety; in the context of a mechanical demolition, the shovel must be located at a distance equal to half the height to ensure the safety of the driver in the event of falling materials. A safety 
perimeter must also be put in place around the machine. A high-rise building must therefore have an available space as large as half its height in the vicinity.

However, this relative insulation of the building is also necessary to a caving operation. The urban morphology of the neighbourhoods of large complexes also makes it a favourable criterion related to the possible choice between nibbling and caving; the discontinuity of the structure of large buildings is suitable for demolition by explosives. Moreover, the more numerous cases of these 'monumental' demolitions have led companies to create a new technique: clipping. This technique involves gradually demolishing up and down the building, up to a certain height to finish nibbling. This can be done by shovelling or sawing at the top of the building; the concrete blocks are sawn and then lowered one after the other.

This last technique, created to cope with monumentality, is an indicator of the impact of the demolitions of large buildings on the economic sector of demolition. Another indicator is the strong structuring of the economic sector, with many companies specializing in demolition (while previously doing other activities) or even specializing in explosive demolition. In this sense, the demolition of large buildings seems to play in France, as part of PNRU, a role similar to that of their construction in the building industry in the post-war period.

\section{Producing large volumes of waste}

Another concrete aspect of demolition, namely, demolition waste, is highlighted when tearing down large complexes, particularly a 'monumental' building. Demolition practices are largely framed by the issue of waste produced (Mongeard \& Santos 2016). The law of Energy Transition for Green Growth of 18 August 2015 supports the objectives set by the 2008 European Framework Directive and imposes non-hazardous waste recovery objectives (to reduce the amount of non-hazardous waste sent to landfill sites by $30 \%$ by 2020 and $50 \%$ by 2025).

To achieve these objectives, the demolition is organised in a succession of steps to remove the elements of the second work. Dangerous materials are removed first by depollution. Next, recyclable materials or materials that would harm the quality of rubble are removed during the building cleaning. During these stages, waste is sorted and sent to suitable channels, after which the empty building can be demolished, giving way to rubble and recoverable inert waste, depending on the materials in question.

The buildings demolished as part of the PNRU are mostly concrete, having been built after the war. These buildings represent particularly interesting materials; the concrete can be easily recoverable after crushing, to be used either as an embankment foundation to restore the site or as a road underlay. The issue of waste management, however, is exacerbated by the monumentality of buildings, which corresponds to very large quantities of waste. As an illustration, a 7-storey bar containing 233 flats corresponds to approximately 27,000 tons of inert waste when a truck carries 20 tons of material per load. The demolition of monumental buildings requires extensive preparation to the building itself and in terms of rubble management: rubble must be sorted and broken into smaller pieces (Fig. 5) before being crushed on site - allowing it to be used to restore the site or to be evacuated to a recycling platform, where it is transformed and sold for new uses.

\section{A very visible demolition mitigated or underlined}

The demolition of slabs and towers, as well as other monumental buildings, requires a significant amount of time due to its duration and magnitude, either due to the demolition technique or merely waste management. Demolition of slabs and towers is essentially a very visible demolition, whereas ordinary demolition is generally invisible. The two 


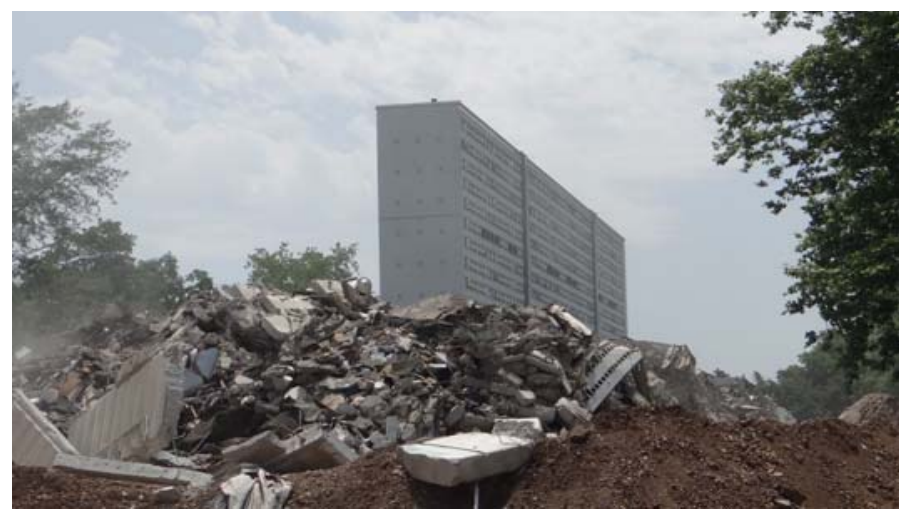

Figure 5. Rubble after demolition with explosive, Lyon La Duchère (2015)

main techniques mentioned - nibbling and caving - are therefore allowed for these types of buildings, and the choice between them appears to correspond more to politics than to the desired visibility desired of the operation.

Interviews with demolition professionals in the Lyon area (social landlords, primary contractors, and demolition companies) between 2012 and 2016 allowed us to examine the parameters considered when choosing the demolition technique to be implemented in the framework of operations of the PNRU. The first criterion, imposed by the conditions of nibbling and caving, is technical: for 10 stories and under, nibbling is preferred, as it is easy to implement; for 15 stories and higher, explosives are preferred. Between these two heights, a structural study is necessary to evaluate the most appropriate technique while also considering economic factors. Thus, beyond 50 metres, nibbling is impossible, and caving is often required; this solution is to the detriment of clipping because it represents an expenditure but also entails huge risks for workers and the area surrounding the site.

The context of urban renewal may also make it necessary to act quickly to free space for new constructions or to quickly achieve so-called 'sensitive' demolitions. Insofar as depollution and cleaning are equivalent, caving is faster than nibbling in the case of very large buildings. This speed may be sought when there are site constraints with a high impact on local life. Caving is the solution chosen for the demolitions at the Mas du Taureau in Vaulx-en-Velin in 2016, and the inconvenience to public transport traffic was thus reduced over time. Caving was also the solution chosen at La Duchère in Lyon in 2015. Overall, the choice also depends on how one wants to manage time at the building site. In caving, the time allotted for sorting and crushing is more important, and the demolition moment paralyses the entire neighbourhood and potentially areas beyond it. At La Duchère, traffic on the motorway near the neighbourhood had to be interrupted at the time of the explosion because the bar could be seen from the highway. On the other hand, nibbling, which takes longer, allows for a modulation of time at the site, for example, by interrupting the demolition to proceed to a first round of rubble removal.

Given the absence of criteria providing an obvious choice between the two techniques, the political aspect, relative to the 'target' population one wishes to witness the demolition and to the image that the local political powers wish to provide to its intervention, appears important in this context of visible demolition. Caving is frequently associated with a desire to highlight the dynamism and voluntarism of these local 
political powers. Its impact via media coverage can be national, or at least regional. Nibbling, however, is associated with a willingness for discretion, which can also be presented as a respectful approach for the population during a contested demolition, as was the case with Bron-Parilly.

As for the effect on the local population, supporters of caving denounce the 'wallpaper' effect of nibbling, which exposes the interior of homes. Thus, in Vaulx-en-Velin, the demolition of bars with 8-10 floors was performed using explosives to avoid this gradual disappearance of old housing. Supporters of nibbling highlight the trauma caused by the explosion (Fig. 1).

Of lesser importance than the technique of demolition is the choice regarding crushing the materials on the building site or not, which - considering the large quantities involved - carries a political connotation. Crushing on-site allows one to use materials to restore the site or sell them to neighbouring sites - which occurs frequently under the ANRU. This practice reduces the amount of waste discharged and reduces and distributes the flows necessary for their removal over time. On-site crushing, however, is only possible in a large space - for the crushing plant on the one hand and storage management of materials on the other - and is a nuisance for the neighbourhood since it involves longer work hours, noise, vibration, and crushing dust. In fact, while the demolitions carried out in the case of the ANRU are often performed in areas that would allow crushing, one can choose to remove the materials to spare the inhabitants of the neighbourhood.

We hypothesised that monumentality had been the subject of special treatment in urban renewal operations by the implementation of out-of-the-ordinary demolition. If this hypothesis is confirmed, it is for technical reasons, which entail a long project, and because the technical stakes allow a mediatised operation, which involves a political decision in all cases.

\section{Rebuilding on a human scale to end monumentality}

Demolition is not always followed by reconstruction, especially when the aim is to remove housing deemed repulsive and difficult to rent in cities and regions in the grip of an economic crisis. Demolition can also be an occasion to initiate the much-evoked opening up, which entails building a street or a tram line to create a perspective in a housing estate construed as inward-looking. In cases of reconstruction, the structure produced in place of the structure destroyed is implicitly indicative of what 'good' social housing architecture and a 'good' city ought to be. Numerous comments expressed or reported in the daily press or in institutional brochures similarly favour small-scale housing:

- "To replace these towers built in the 1970s and gradually deserted by their inhabitants, Opac plans to install small buildings of up to two floors" ("Minguettes: La tour 44 est tombée hier à midi pour laisser place à de petits immeubles," 20 minutes, 11 June 2004).

Additionally, in Venissieux, a similar type of strategy was presented:

- "The space left vacant by these two demolitions will be used for the construction of detached houses and small buildings." ${ }^{28}$ In Rillieux-la-Pape, the Large City Project issued a communiqué, entitled "New Urbanism and Architecture", which read as follows:

- "To diversify the building silhouettes of the new City, differential heights were reduced, and lower buildings were built. In addition to the ground floor, buildings have no more than 4 or 5 floors, each with a setback terraced apartment" (GPV Rillieux-la-Pape, Le Bottet, brochure collected in September 2016).

Small scale is associated with many positive values, as can be seen at the regional

\footnotetext{
28 http://www.batiactu.com/edito/destruction-unsymbole-a-venissieux-13574.php consulted on 10 September 2015.
} 
or national level by drawing on the already mentioned press corpus.

In the case of the Romans, small scale is a guarantee of recovered 'human warmth':

- "In its place, there will also be a private developer programme with 30 housing units. Smaller and therefore more welcoming buildings with high environmental quality" (Stéphane Milhomme, France Bleu Drôme-Ardèche, 22 January 2015).

More broadly, small scale is associated with 'human scale':

- "The aim is not only to replace degraded tower and slab blocks with human-scale housing but also to turn these stigmatised districts into ordinary pieces of the city" (Tonino Serafini, "Casser les ghettos," Libération, 29 October 2003).

By the same token, 'human scale' is 'urban scale':

- "Recovering the urban dimension of Aixles-Bains in the 'Sierroz-Franklin' districts, especially in terms of building size, social mix, and connection with other districts; opening up, image change." ${ }^{29}$

Associated with privacy and individual property, 'the small' scale - whether small communities or detached houses - is thus very clearly mobilised by those who promote urban renewal; this scale is also opposed to the image of gigantism and dehumanisation linked to these social housing towers. As early as the circular of 30 November 1971, Minister Chalandon maintained that it was necessary "to take into account the rather fundamental aspiration (of) inhabitants to live in individual houses or in buildings of reasonable dimensions".

\section{Conclusion}

The discourse of urban renewal is explicitly aimed at the towers and slabs built after the Second World War. These architectural forms are often monumental. The case of Lyon

\footnotetext{
29 http://www.eco-obs.net/eco-obs/index. php?option=com_content\&id=17\&ltemid $=2$ consulted on 10 September 2015.
}

allows one to observe that this characteristic of monumentality is a factor in the decisionmaking process leading to or circumventing demolition.

Even if monumentality is not a sufficient criterion, it is considered in most cases regarding the decision to demolish or, in contrast, to preserve buildings in a district. The demolished buildings are most often monumental buildings; in contrast, the few recognised and valued buildings, such as the Panoramic Tower at La Duchère in Lyon, are large structures that can be used as visual landmarks throughout the city.

Monumentality is also considered in the choice of demolition technique. While the demolitions carried out upstream of development projects are frequently executed by nibbling and with discretion, those in the framework of the PNRU refer to other conditions of intervention and publicisation. The large size of the targeted buildings makes it possible to demolish using explosives or even necessitate the use of clipping. In a national or regional context that promotes such demolitions, worksites on monumental buildings represent a privileged medium of communication, giving rise to a wide dissemination of images. The extraordinary character of these buildings leads to extraordinary demolition operations, which are at the origin of a structuring of the demolition profession, similar to what transpired in the construction field when producing 'grands ensembles'.

The challenge of these interventions is ultimately to remove, with a few exceptions, the most emblematic buildings of the period of construction of large complexes and trivialise these neighbourhoods of social housing. As we have seen, reconstruction carried out following the demolition of towers and bars systematically avoids monumentality.

Editors' note:

Unless otherwise stated, the sources of tables and figures are the authors', on the basis of their own research. 


\section{References}

AgENCE D'URBANISME DE L'AIRE MÉTROPOLITAINE LYONNAISE, 2011. Atlas du logement locatif et social du Grand-Lyon. Directeur de la publication: Olivier Frerot.

Berland-Berthon A., 2009. La Démolition des immeubles de logements sociaux. Histoire urbaine d'une non-politique publique. Paris: Éditions du CERTU.

ChÉDIAC S., 2009. A la maison dans mon HLM... La résidentialisation comme dispositif de rénovation urbaine, Métropoles [En ligne], 5 | 2009, mis en ligne le 06 avril 2009, consulté le 21 mai 2017, http://metropoles.revues.org/3775 [21 May 2017].

Clémençon A.-S., Traverso E., Lagier A., 2004. Les Gratte-Ciel de Villeurbanne. Besançon: Éditions de l'imprimeur.

Cuomo A., 1999. HOPE VI: Building Communities, Transforming Lives, U.S. Department of Housing and Urban Development, December.

Deboulet A., Lelévrier C., 2014. Rénovation urbaine en Europe. Rennes: Presses Universitaires de Rennes.

DekKer K., Van Kempen R., 2004. Large housing estates in Europe: current situation and developments. In: Tijdschrift voor Economische en Sociale Geografie, vol. 95, no. 5, pp. 570-577.

De Portzamparc Ch., et al., 1999. Où sont les monuments aujourd'hui? [in :] R. Debray (ed.), L'abus monumental, Actes des entretiens du patrimoine, no. 4, Paris: Fayard-éditions du patrimoine, pp. 389-408.

Donzelot J., 2012. A quoi sert la rénovation urbaine?. Paris: Presses universitaires de France.

Droste C., Lelévrier C., Wassenberg F., 2008. Urban regeneration in European social housing areas [in:] C.M.E. Whitehead, K. Scanlon (eds.), Social Housing in Europe II : A review of policies and outcomes, London: London School of Economics and Political Science, pp. 163-196.

Dufaux F., Fourcaut A. (eds.), 2004. Le monde des grands ensembles Paris: Éditions Créaphis.

EPSTEIN R., 2013. La rénovation urbaine: démolition-reconstruction de l'Etat. Paris: Les Presses de Sciences Po.

FORTIN J.-P., 2005. Des tours et des barres: une histoire du grand ensemble relue par un architecte.
Informations Sociales, vol. 123, no. 3, pp. 116-125.

FREY J.-P., 2011. Un objet de controverse: la monumentalité entre architecture et forme urbaine [in:] I. losa, M. Gravari-Barbas (eds.), Monumentalité(s) urbaine(s) aux XIXe et XXe siècles: Sens, formes et enjeux urbains, Paris: L'Harmattan, pp. 207-226.

Genestier P., Veschambre V., 2017. La démolition des tours et des barres comme évidence: les cadres du récit de la rénovation urbaine [in:] Y. Fijalkov (ed), Dire la ville, c'est faire la ville: la performativité des discours sur l'espace urbain, Villeneuve d'Ascq: Presses universitaires du Septentrion, pp. 85-98.

Gravari-Barbas M., Iosa I., 2006. Monumentalité urbaine: formes, sens et enjeux des pouvoirs urbains, Annonce du colloque, Fondation Hellenique, 10 mai 2006, https://fondation-hellenique.fr/monumentalite-urbaine-formes-senset-enjeux-des-pouvoirs-urbains/ [20 December 2018].

HUD, 1996. Public housing that works: The transformation of America's public housing. Office of Policy Development and Research (PD\&R), May 1996.

Kaddour R., 2015. Les représentations complexes des tours d'habitat populaire: La trajectoire en trois actes de la tour Plein-Ciel à SaintÉtienne. 9 December 2015, Métropolitique, http://www.metropolitiques.eu/Les-representations-complexes-des.html [20 December 2018].

Ministère de la Culture et de la communication, 2011. Les Grands Ensembles, une architecture du XXe siècle. Paris: Éditions Dominique Carré.

Mongeard L., Santos Eder C.G., 2017. Recyclage des déchets de chantier dans l'habitat populaire en France et au Brésil [in:] D. Paris (ed.), Vivre le territoire et faire la ville autrement?: Regards croisés franco-brésiliens, Villeneuve-d'Ascq: Presses Universitaires du Septentrion, pp. 203-220.

Pinçon M., Pinçon-Charlot M., 2002. Le patrimoine habité [in:] M. Segaud, J. Brun, J.C. Driant (ed.), Dictionnaire de l'habitat et du logement, Paris: Armand Colin, pp. 319-323.

REY J., 2010. Lyon, cité radieuse. Une aventure du Mouvement moderne international. Lyon: Éditions Libel. 
VAYSSIÈRE B., 1988. Reconstruction-déconstruction. Le Hard French ou l'architecture des trente glorieuses. Paris: Editions Picard.

VesChAMBRE V., 2011. La rénovation urbaine dans les grands ensembles: de la monumentalité à la banalité ? [in:] I. losa, M. Gravari-Barbas, Monumentalité(s) urbaine(s) aux XIXe et XXe siècles: Sens, formes et enjeux urbains, Paris: L'Harmattan, pp. 193-206.

Vieillard-BARON H., 2004. Les grands ensembles: spécificités françaises et diversité des modèles étrangers [in:] Dufaux F., Fourcaut A. (eds.), Le monde des grands ensembles, Paris: Éditions Créaphis. 